\title{
The natural product Aristolactam Allla as a new ligand targeting the polo-box domain of polo-like kinase 1 potently inhibits cancer cell proliferation
}

\author{
$\mathrm{Li} \mathrm{LI}^{1, \#}$, Xu WANG ${ }^{2, \#}$, Jing $\mathrm{CHEN}^{2, *}$, Hong DING ${ }^{2}$, Yu ZHANG ${ }^{2}$, Tian-cen $\mathrm{HU}^{2}$, Li-hong HU ${ }^{2, *}$, Hua-liang JIANG ${ }^{1,2}, \mathrm{Xu} \mathrm{SHEN}^{1,2}$ \\ ${ }^{1}$ School of Pharmacy, East China University of Science and Technology, Shanghai 200237, China; ${ }^{2}$ Drug Discovery and Design Cen- \\ ter, State Key Laboratory of Drug Research, Shanghai Institute of Materia Medica, Chinese Academy of Sciences, Shanghai 201203, \\ China
}

Aim: To search for novel inhibitors of human polo-like kinase 1 (PIk1), which plays important roles in various aspects of mitotic progression and is believed as a promising anti-cancer drug target, and further investigate the potential inhibition mechanism of active compounds against Plk1, thus developing potent anti-tumor lead compounds.

Methods: Surface plasmon resonance (SPR) technology-based assay and enzymatic inhibition assay were used to screen PIk1 inhibitors. Sulphorhodamine B (SRB)-based assay, flow cytometry, confocal microscopy and Western blotting were used to further identify the potent PIk1 inhibitor. To investigate the inhibitory mechanism of the active compound against PIk1, enzymatic inhibition assay, SPR and yeast two-hybrid technology-based assays were used.

Results: Aristolactam Allla was identified as a new type of Plk1 inhibitors, targeting the Polo Box domain (PBD) which is another efficient tactic for exploring Plk1 inhibitors. Further studies indicated that it could block the proliferations of HeLa, A549, HGC and the HCT-8/V cells (clinical Navelbine-resistant cancer cell), induce mitotic arrest of HeLa cells at $\mathrm{G}_{2} / \mathrm{M}$ phase with spindle abnormalities and promote apoptosis in HeLa cells. The results from SPR and yeast two-hybrid technology-based assays suggested that it could target both the catalytic domain of PIk1 (CD) and PBD and enhance the CD/PBD interaction.

Conclusion: Our current work is expected to shed light on the potential anti-tumor mechanism of Aristolactam Allla, and this natural product might be possibly used as a lead compound for further developing anti-tumor drugs.

Keywords: antitumor drugs; Aristolactam Allla; Polo-box domain; Polo-like kinase 1 inhibitor

Acta Pharmacologica Sinica (2009) 30: 1443-1453; doi: 10.1038/aps.2009.141

\section{Introduction}

Polo-like kinases (Plks) belong to a family of Ser/Thr protein kinases and play a variety of roles in cell cycle progression ${ }^{[1]}$. To date, four members of this family have been identified in mammalian cells, termed as Plk1, Plk2 (SNK), Plk3 (PRK/ FNK), and Plk4 (SAK $)^{[2-6]}$, of which Plk1 is the best characterized. It has been discovered that Plk1 functions importantly in numerous aspects of mitotic progression, including controlling entry into mitosis through the activation of the cdc2/ cyclinB complex $^{[7]}$, centrosome maturation ${ }^{[8]}$, bipolar spindle formation $^{[8]}$, sister chromatid separation ${ }^{[9]}$, anaphase promot-

\footnotetext{
\# These authors contributed equally to this article.

* To whom correspondence should be addressed.

E-mail jingchen@mail.shcnc.ac.cn (Jing CHEN) simmhulh@mail.shcnc.ac.cn (Li-hong HU)

Received 2009-07-09 Accepted 2009-08-19
}

ing complex activation ${ }^{[10]}$ and affecting cytokinesis by phosphorylating NudC ${ }^{[11]}$, etc. Overexpression of Plk1 has been observed in many human tumors including non-small cell lung cancer, oropharyngeal carcinoma, esophageal carcinoma, gastric carcinoma, melanoma, breast cancer, ovarian cancer, endometrial cancer, colorectal cancer, glioblastoma, papillary carcinoma, pancreatic, prostate, hepatoblastoma, and nonHodgkin's lymphoma ${ }^{[12]}$. In addition, Plk1 expression is also considered to be of prognostic value for patients suffering from varied types of tumors. Furthermore, microinjection of Plk mRNA was proved to be sufficient to drive quiescent cells into mitosis, and constitutive expression of Plk in NIH 3T3 cells could cause oncogenic focus formation ${ }^{[13]}$. Meanwhile, phosphorothioate antisense oligonucleotides (ASONs) against Plk1 showed potent anti-proliferative effect in cell culture and in mouse xenograft studies ${ }^{[14,15]}$. Therefore, all these abovementioned results have made Plk1 a potent target for the dis- 
covery of anti-tumor agents.

Structurally, Plks are homologous and contain two conserved domains, the N-terminal catalytic kinase domain (CD) and the C-terminal polo box domain (PBD) that is composed of so-called polo boxes. The PBD exhibits a critical role in the regulation of Plk1's kinase activity and the subcellular localization of $P l k 1^{[16]}$. It has been reported that Plk1 interacts, through its PBD, with certain serine/threonine-phosphorylated proteins localized at particular mitotic apparatuses, and binding of the PBD to the primed phosphorylation sites not only serves for targeting the kinase domain to substrates but also simultaneously activates the kinase domain by relieving the inhibitory intramolecular interaction ${ }^{[17]}$. Therefore, in addition to blocking the ATP-binding or the substrate-binding site, targeting the PBD is also considered as another efficient tactic for the exploration of Plk1 inhibitors.

The first published small molecular Plk1 inhibitor was scytonemin, a natural marine product isolated from cyanobacteria $^{[18,19]}$, which is a micromolar non-specific ATP competitor. The pharmacophore ON01910 was a non-ATP competitive inhibitor of Plk1, which was probably a substrate-competitive inhibitor of recombinant casein and CDC25 $C^{[20]}$. The first small molecule inhibitor targeting the PBD was reported recently ${ }^{[21]}$, which could interfere with Plk1 intracellular localization by inhibiting the function of the PBD.

In the current work, by random screening against our inhouse natural product library, we discovered that the natural product Aristolactam AIIIa (Figure 1A), an Aristolactam derivative $^{[22]}$, functions as a new type of ligand targeting the PBD. It could inhibit the proliferation of cancer cells and induce apoptosis and the mitotic arrest at $G_{2} / M$ phase with spindle abnormalities. Different from the published Plk1 inhibitors, this natural product not only targeted both the CD and PBD domains, but also enhanced the CD/PBD interaction. Our findings might help to shed light on the possible mechanism of the Aristolactams inhibition against cancer cell proliferation $^{[23,24]}$, and Aristolactam AIIIa might be used as a potential lead compound for further research.

\section{Materials and methods}

\section{Plasmid construction}

The PBD (residues 326-603 of Plk1) and the catalytic domain of Plk1 (CD, residues 1-370 of Plk1) were amplified by PCR from pUC18-Plk1 (synthesized by Shanghai Sangon Biological Engineering Technology \& Services Co, Ltd, Shanghai, China), and then subcloned into the vector pGEX4T-1 and pFastBacHTb, respectively. For the yeast two-hybrid assay, the DNA fragment encoding the PBD was digested with EcoR I and Xho I (NEB) from the pGEX4T-1-PBD plasmid and then cloned into the pGADT7 vector. Similarly, the catalytic domain of Plk1 was cloned into the pGBKT7 vector from pFsatBacHTA-CD. For overexpression, the PBD and CD were amplified by PCR from pUC18-Plk1 and then subcloned into the vector pCDNA3.1a, respectively.

\section{Protein preparation}

By using pGEX4T-1-PBD as the expression plasmid, the recombinant protein GST-tagged PBD was expressed in E coli BL21 (DE3) cells and purified by glutathione-affinity chromatography. The GST tag was cleaved on column with thrombin (Pharmacia) and the native PBD was obtained by gel filtration. The His-tagged catalytic domain of Plk1 was expressed in TN insect cells (TN-5B1-4, Trichoplusia Ni) using standard baculovirus expression protocols and purified with Ni-NTA affinity chromatography.

\section{In vitro enzymatic assays of the full-length PIk1 and its catalytic domain}

The enzymatic assays of Plk1 and its catalytic domain were performed using the Cyclex Plk1 assay kit/inhibitor screening kit (Cyclex Co, Japan). Kinase inhibition experiments were carried out according to the protocol provided by the manufacturer. Plates were precoated with the substrate termed recombinant Protein- $X$, which contains a threonine residue that can be phosphorylated by Plk1. The detector antibody specifically detects the phosphorylated threonine on Protein- $X$. During the assay, Plk1 or its catalytic domain was dissolved in $10 \mu \mathrm{L}$ kinase buffer and mixed with $10 \mu \mathrm{L}$ of compound solution at different concentrations (prepared by diluting $1 \mu \mathrm{L}$ of DMSO mother liquor into $9 \mu \mathrm{L}$ kinase buffer). The mixture was finally added to $80 \mu \mathrm{L}$ of kinase buffer containing $50 \mu \mathrm{mol} / \mathrm{L}$ ATP. After pre-incubation at $4{ }^{\circ} \mathrm{C}$ for $80 \mathrm{~min}$, the plates were incubated at $30{ }^{\circ} \mathrm{C}$ for $30 \mathrm{~min}$, and the wells were washed five times with $1 \times$ wash buffer provided by the manufacturer. Subsequently, $100 \mu \mathrm{L}$ of anti-phospho-threonine polyclonal antibody (PPT-07) was added to each well and incubated at room temperature for $30 \mathrm{~min}$. The wells were washed five times as described above and incubated with $100 \mu \mathrm{L}$ of HRPconjugated anti-rabbit IgG. Following a 30-min incubation at room temperature, the wells were washed five times and incubated with $100 \mu \mathrm{L}$ of a chromogenic substrate reagent for $5 \mathrm{~min}$. The reaction was terminated with $100 \mu \mathrm{L}$ stop solution, and the amount of phosphorylated substrate was determined by measuring the absorbance at dual wavelengths of 450/540 nm.

\section{Immunoprecipitation}

For Plk1 immunoprecipitation, HeLa cells $\left(4 \times 10^{6}\right.$ cells/well) were seeded on 10-mm dish and incubated overnight. After incubation with nocodazole $(5 \mu \mathrm{g} / \mathrm{mL})$ for $12 \mathrm{~h}$, the cells were lysed with $500 \mu \mathrm{L}$ cold lysis buffer containing a protease inhibitor cocktail. The cell lysate was treated with $500 \mu \mathrm{L}$ of lysis buffer containing $10 \mu \mathrm{L}$ of a prepared protein A/G bead slurry $1 \mathrm{~h}$ at $4^{\circ} \mathrm{C}$ and then centrifuged at $13000 \mathrm{r} / \mathrm{min}$ for $15 \mathrm{~min}$ at $4{ }^{\circ} \mathrm{C}$. The supernatant was carefully collected without disturbing the pellet and transferred to a clean tube, followed by incubation with $10 \mu \mathrm{L}$ of Plk1 antibody (1:50, 35-306 aa, Abcam) overnight. After incubated with $20 \mu \mathrm{L}$ pre-cleared protein A/G bead slurry at $4^{\circ} \mathrm{C}$ for $3 \mathrm{~h}$ on a rotator, the mixture was spun at $13000 \mathrm{r} / \mathrm{min}$ for $2 \mathrm{~min}$ at $4{ }^{\circ} \mathrm{C}$. The supernatant was 
carefully removed and the beads were washed twice with 50 $\mu \mathrm{L}$ kinase buffer. After the final wash, the agarose beads were resuspended in $50 \mu \mathrm{L}$ kinase buffer and mixed gently. The catalytic domain of Plk1 (residues 1-370 of Plk1) that was transiently transfected into $293 \mathrm{~T}$ cells for $48 \mathrm{~h}$ was immunoprecipitated with an anti-myc antibody (1:400, Invitrogen).

\section{Sulfphorhodamine B-based assay for cell proliferation}

The quantitative sulphorhodamine B (SRB) colorimetric assay $^{[25]}$ was used for determining the inhibition of Aristolactam AIIIa against HGC, A549, HeLa, and HCT-8/V cancer cells. Cells were seeded onto a 96-well plate with 5000 cells per well and incubated at $37^{\circ} \mathrm{C}$ for $24 \mathrm{~h}$. The cells were treated with increasing concentrations of Aristolactam AIIIa for another $72 \mathrm{~h}$, fixed with $10 \%$ trichloracetic acid for $1 \mathrm{~h}$ at $4{ }^{\circ} \mathrm{C}$, air-dried, and then stained at room temperature for 20 min with $4 \mathrm{mg} / \mathrm{mL}$ SRB solution. Cells were subsequently washed with $1 \%$ acetic acid five times and dissolved in $150 \mu \mathrm{L}$ of $10 \mathrm{mmol} / \mathrm{L}$ Tris buffer. The cell viability was presented as absorbance at $515 \mathrm{~nm}$ (Benchmark Plus ${ }^{\mathrm{TM}}$ microplate spectrophotometer, BIO-RAD) and averaged from three replicates. The values were obtained from three independent experiments. NVB (Navelbine) and DMSO were used as positive and negative controls, respectively. All cell culture reagents were purchased from Gibco.

\section{Analysis of cell cycle progression}

HeLa cells $\left(3 \times 10^{4}\right.$ cells/well) were seeded onto 6 -well plates and incubated overnight. After being incubated with Aristolactam AIIIa $(10 \mu \mathrm{mol} / \mathrm{L})$ for 24 or $48 \mathrm{~h}$, the adherent cells were detached with trypsin, and the floating cells were collected by centrifugation at $600 \times g$ for $10 \mathrm{~min}$. The cells were washed twice with PBS, fixed in $75 \%$ ethanol-PBS at $4{ }^{\circ} \mathrm{C}$ for $2 \mathrm{~h}$, and then collected by centrifugation. Cells were resuspended with $500 \mu \mathrm{L}$ PBS containing $100 \mathrm{mg} / \mathrm{mL}$ RNase A and incubated for $30 \mathrm{~min}$ at $37^{\circ} \mathrm{C}$, followed by filtration and staining with $0.5 \mathrm{mg} / \mathrm{mL}$ propidium iodide (PI) for $1 \mathrm{~h}$. The suspensions were then analyzed by Becton Dichinson FACScan (BD Biosciences, San Jose, CA). The percentage of cells in the $\mathrm{G}_{0} / \mathrm{G}_{1}, \mathrm{G}_{2} / \mathrm{M}$ phases of the cell cycle was determined by the DNA contents.

\section{Confocal microscopy}

HeLa cells grown on glass coverslips were washed with PBS and fixed in $4 \%$ paraformaldehyde. After washed with PBS for $5 \mathrm{~min}$, the fixed cells were treated with PBS containing $1 \%$ Triton at room temperature for $10 \mathrm{~min}$ and then washed with PBS containing $0.02 \%$ Tween 20 for $5 \mathrm{~min}$. To image the spindle apparatus, the fixed cells were incubated with a FITC-conjugated monoclonal anti-a-tubulin antibody (DM1A, Sigma) at a $1: 100$ dilution and propidium iodide (PI) at $37^{\circ} \mathrm{C}$ for $45 \mathrm{~min}$. In Plk1 localization assay, the antibodies used were the mouse monoclonal antibody (mAb) anti-Plk1 (1:200; 35-306 aa; Abcam) and the Alexa Fluor 488-conjugated goat anti-mouse (1:1000; Invitrogen) antibody. DNA was stained with PI. Coverslips were washed with PBS, 50\% glycerol was applied on the slide, and the coverslip was added on top with the cells facing the glycerol and sealed with glycerol. The stained cells were imaged by the confocal microscope (Leica, German) with a $63 \times$ objective.

\section{Apoptosis assay}

HeLa cells $\left(3 \times 10^{4}\right.$ cells/well) were seeded onto 24 -well plates and, after overnight incubation, the cells were incubated with Aristolactam AIIIa $(10 \mu \mathrm{mol} / \mathrm{L})$ for $24 \mathrm{~h}$. The PARP cleavage assay was performed with equal amounts of total cellular proteins that were resolved on a 10\%-SDS-polyacrylamide gel, and Western blotting analysis was performed using anti-PARP antibodies (BD Biosciences).

In Annexin $\mathrm{V}$ apoptosis assay, HeLa cells were seeded onto six-well plates and after overnight incubation, cells were incubated with Aristolactam AIIIa $(10 \mu \mathrm{mol} / \mathrm{L})$ for $24 \mathrm{~h}$. Cells were trypsinized and incubated with Annexin $\mathrm{V}$ according to the manufacturer's recommendations (Calbiochem).

\section{Surface plasmon resonance (SPR) technology-based binding assay}

The binding of Aristolactam AIIIa to the PBD or CD was analyzed by SPR technology-based Biacore 3000 instrument (Biacore $A B$, Uppsala, Sweden). All experiments were carried out using HBS-EP (10 mmol/L HEPES pH 7.4, $150 \mathrm{mmol} / \mathrm{L} \mathrm{NaCl}$, $3.4 \mathrm{mmol} / \mathrm{L}$ EDTA and $0.005 \%$ surfactant P20) as running buffer with a constant flow rate of $30 \mu \mathrm{L} / \mathrm{min}$ at $25{ }^{\circ} \mathrm{C}$. The PBD protein, which was diluted in $10 \mathrm{mmol} / \mathrm{L}$ sodium acetate buffer ( $\mathrm{pH} 4.2$ ) to a final concentration of $2 \mu \mathrm{mol} / \mathrm{L}$, was covalently immobilized on the hydrophilic carboxymethylated dextran matrix of the CM5 sensor chip (BIAcore) using standard primary amine coupling procedure. The CD protein, which was diluted in $10 \mathrm{mmol} / \mathrm{L}$ sodium acetate buffer ( $\mathrm{pH} 4.13)$ to a final concentration of $2 \mu \mathrm{mol} / \mathrm{L}$, was immobilized on the chip using the same procedure. Aristolactam AIIIa was dissolved in the running buffer at different concentrations ranging from 1 to $10 \mu \mathrm{mol} / \mathrm{L}$. All data were analyzed by BIAevaluation software, and the sensorgrams were processed by automatic correction for nonspecific bulk refractive index effects. The kinetic analyses of the Aristolactam AIIIa/PBD binding were performed based on the steady state affinity fit model according to the procedures described in the software manual, and the Aristolactam AIIIa/CD binding equilibrium dissociation constant was calculated based on the 1:1 Langmuir binding fit model.

To investigate the effect of Aristolactam AIIIa on the PBD/ $\mathrm{CD}$ interaction, the purified CD protein was immobilized on a CM5 sensor chip. After the PBD $(14 \mu \mathrm{mol} / \mathrm{L})$ was incubated with different concentrations of Aristolactam AIIIa (0, 24, 34.3, $49,70$, and $100 \mu \mathrm{mol} / \mathrm{L})$ for $1 \mathrm{~h}$, the samples were applied to the sensor chip at a flow rate of $10 \mu \mathrm{L} / \mathrm{min}$ for $60 \mathrm{~s}$, followed by washing with HBS-EP $180 \mathrm{~s}$. The binding ability of PBD towards the CD was reflected by RUs values recorded directly by the Biacore 3000 instrument. 


\section{Yeast two-hybrid assay}

Competent cells of the yeast strain AH109 were obtained from Clontech (Plano Alto, CA), and transformations were performed according to the manufacturer's protocol. First, $500 \mathrm{ng}$ of plasmid DNA was added to $50 \mu \mathrm{L}$ of competent cells and mixed with $36 \mu \mathrm{L}$ of $1 \mathrm{~mol} / \mathrm{L}$ lithium acetate, $5 \mu \mathrm{L}$ of boiled 10 $\mathrm{mg} / \mathrm{mL}$ ss-carrier DNA and $240 \mu \mathrm{L}$ of $50 \%$ poly(ethylene glycol) (MW3350) at $30{ }^{\circ} \mathrm{C}$ for 30 min followed by heat-shock at $42{ }^{\circ} \mathrm{C}$ for $30 \mathrm{~min}$ and subsequently spread on a drop-out-agar plate that lacked leucine and tryptophan. The plates were incubated at $30^{\circ} \mathrm{C}$ for $48 \mathrm{~h}$ to allow for yeast growth. PCR was used to confirm the transformation of the target plasmids. A positive clone was inoculated into SD medium lacking leucine and tryptophan (SD-LT) overnight, the culture was then diluted to OD600 of 0.003 with SD medium lacking leucine, tryptophan, and histidine (SD-LTH) which was supplemented with $2 \mathrm{mmol} / \mathrm{L}$ of 3-amino-10,20,40-triazole (SD-LTH+3-AT) and $100 \mu \mathrm{mol} / \mathrm{L}$ of Aristolactam AIIIa. The medium was shaken at $250 \mathrm{r} / \mathrm{min}$ at $30{ }^{\circ} \mathrm{C}$ for $48 \mathrm{~h}$ before $200 \mu \mathrm{L}$ of the culture was added to the well of a 96-well microplate. The absorbance at $600 \mathrm{~nm}$ of the culture in the 96-well microplate was then measured by a Benchmark Plus ${ }^{\mathrm{TM}}$ microplate spectrophotometer (BIO-RAD). This is an alternative method based on the growth curve analysis for yeast culture that is amenable to a microtiter plate format. It is reproducible and of equal or greater sensitivity compared with the $\beta$-galactosidase assay ${ }^{[26]}$. All the yeast media were prepared according to the standard Protocols Handbook (PT3024-1, Clontech).

\section{Results}

\section{Aristolactam Allla inhibits Plk1 activity}

To evaluate the inhibition of Aristolactam AIIIa against Plk1, the Polo-like kinase1 Assay/Inhibitor Screening Kit (Cyclex Co, Japan) was used. During the assay, 1.25 munits of recombinant Plk1 (Cyclex Co, Japan) was mixed with different concentrations of either Aristolactam AIIIa or DMSO (as a control), and the kinase activity was measured by using Protein- $X$ as substrate. As indicated in Figure 1B, the natural product Aristolactam AIIIa exhibited a dose-dependent inhibition against Plk1-mediated phosphorylation of Protein- $X$ with an $\mathrm{IC}_{50}$ value of $47.5 \mu \mathrm{mol} / \mathrm{L}$.

In order to further confirm the inhibition of Aristolactam AIIIa against Plk1, the kinase activity of endogenous Plk1 immunoprecipitated from Nocodazole-arrested HeLa cells was measured after incubation with Aristolactam AIIIa (10 $\mu \mathrm{mol} / \mathrm{L}$ and $100 \mu \mathrm{mol} / \mathrm{L}$ ) or DMSO (as a control). As shown in Figure 1C, Aristolactam AIIIa also inhibited the endogenous Plk1 activity in a dose-dependent manner.

To investigate the potential selectivity of Aristolactam AIIIa against Plks, the inhibition of Aristolactam AIIIa against

B
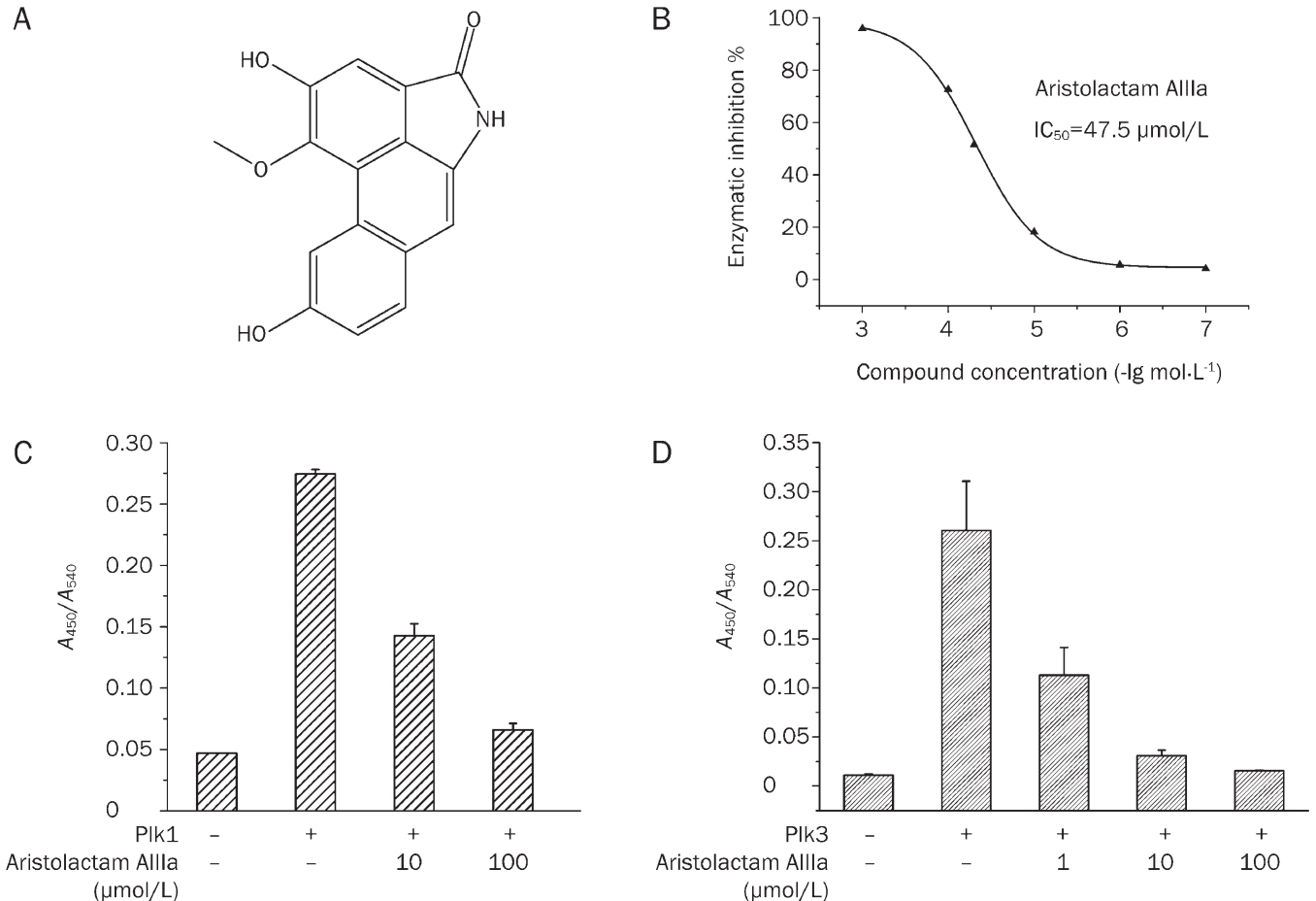

Figure 1. Aristolactam Allla could inhibit the Plk1 catalytic activity. (A) Structure of Aristolactam Allla. (B) Inhibition of Aristolactam Allla against Plk1 catalytic activity. Plk1 $\left(1.25 \times 10^{-3}\right.$ units $)$ was pre-incubated with Aristolactam Allla at different concentrations, and the inhibited Plk1 activity was presented as percentage of the maximal inhibition. $\boldsymbol{\Delta}$, Aristolactam Allla $(0.1,1,5,10,50,100$, and $1000 \mu \mathrm{mol} / \mathrm{L})$. All data were averaged from three independent experiments. Half-maximal inhibitor concentrations ( $\mathrm{IC}_{50}$ values) were obtained by sigmoidal fit of inhibitory curves using Origin 7.0. (C) Inhibition of Aristolactam Allla against the endogenous Plk1 enzyme immunoprecipitated from mitotic cells (Nocodazole-arrested HeLa cells). PIk1 was pre-incubated with Aristolactam Allla (10 and $100 \mu \mathrm{mol} / \mathrm{L}$ ) or DMSO for $1 \mathrm{~h}$. (D) Inhibition of Aristolactam Allla against Plk3 catalytic activity. PIk3 was pre-incubated with Aristolactam Allla (1, 10, and $100 \mu \mathrm{mol} / \mathrm{L})$ or DMSO for $1 \mathrm{~h}$. 
Plk3 was measured with a Polo-like kinase3 Assay/Inhibitor Screening Kit (Cyclex Co, Japan). As shown in Figure 1D, Aristolactam AIIIa exhibited a dose-dependent inhibition against Plk3, indicating that Aristolactam AIIIa had no selectivity for Plks.

Aristolactam Alla inhibits the proliferation of human HeLa, A549, HGC, and HCT-8/V cells

As has been reported ${ }^{[24]}$, some Aristolactam derivatives could exhibit cytotoxicity against KB, P388, A549, HT29, HL60, HeLa, and L1210 cells, but no detailed inhibition mechanism was investigated. Although Aristolactam AIIIa has been reported to inhibit platelet aggregation induced by collagen and AA, its anti-tumor activity has not yet been elucidated ${ }^{[27]}$. Here, the anti-proliferation effect of Aristolactam AIIIa on HeLa, A549, and HGC cancer cell lines was examined. As shown in Table 1 and Figure 2A, Aristolactam AIIIa inhibited the proliferation of these cancer cells in a dose-dependent manner with $\mathrm{IC}_{50}$ values ranging from 7 to $30 \mu \mathrm{mol} / \mathrm{L}$. Moreover, to further explore the potential inhibition of Aristolactam AIIIa against the relevant clinical drug-resistant cancer cell, the Navelbine (NVB)-resistant HCT-8/V cell line was assayed. As indicated in Figure 2B and Table 2, Aristolactam AIIIa exhibited dosedependent inhibitory effects on $\mathrm{HCT}-8 / \mathrm{V}$ with an $\mathrm{IC}_{50}$ of $3.55 \mu \mathrm{mol} / \mathrm{L}$, even while $10 \mu \mathrm{mol} / \mathrm{L}$ of NVB had no effect on HCT-8/V proliferation.

Table 1. Anti-proliferation activity of Aristolactam Allla against different cancer cell lines.

\begin{tabular}{lccc}
\hline Cancer cell line & HeLa & A549 & HGC \\
\hline $\mathrm{IC}_{50}(\mu \mathrm{mol} / \mathrm{L})$ & 7.98 & 15 & 31 \\
\hline
\end{tabular}

Table 2. Susceptible property of clinical drug-resistant cell line HCT-8/V to Aristolactam Allla.

\begin{tabular}{ll}
\hline & $\mathrm{IC}_{50}(\mu \mathrm{mol} / \mathrm{L})$ \\
\hline Aristolactam Allla & 3.55 \\
NVB & $\mathrm{NI}$ \\
\hline
\end{tabular}

$\mathrm{NI}$ : no inhibition at $10 \mu \mathrm{mol} / \mathrm{L}$.

\section{Aristolactam Allla induces cell cycle arrest in the $G_{2} / M$ phase} with spindle abnormalities in HeLa cells

Plk1 was shown to be essential to mitotic progression and cytokinesis, and functional down-regulation of Plk1 (either by microinjecting Plk1-specific antibodies or overexpressing dominant-negative Plk1) might induce $\mathrm{G}_{2} / \mathrm{M}$ arrest ${ }^{[8,28]}$. With these facts in mind, we thereby investigated the potential effect of Aristolactam AIIIa on the cell cycle of tumor cells. As shown in Figure 2C, incubation of HeLa cells with $10 \mu \mathrm{mol} / \mathrm{L}$ of Aristolactam AIIIa for $24 \mathrm{~h}$ increased the cell population staying in
$\mathrm{G}_{2} / \mathrm{M}$ phase by $100 \%$ compared with the control cells, which thus suggested that Aristolactam AIIIa was able to induce cell cycle arrest at the $\mathrm{G}_{2} / \mathrm{M}$ phase. To further confirm this result, the cell cycle distribution pattern of HeLa cells treated for $48 \mathrm{~h}$ with Aristolactam AIIIa or DMSO was also investigated. As shown in Figure S1, similar to the case in $24 \mathrm{~h}$ incubation, a $48 \mathrm{~h}$ incubation with Aristolactam AIIIa could also induce cell cycle arrest in $\mathrm{G}_{2} / \mathrm{M}$ phase.
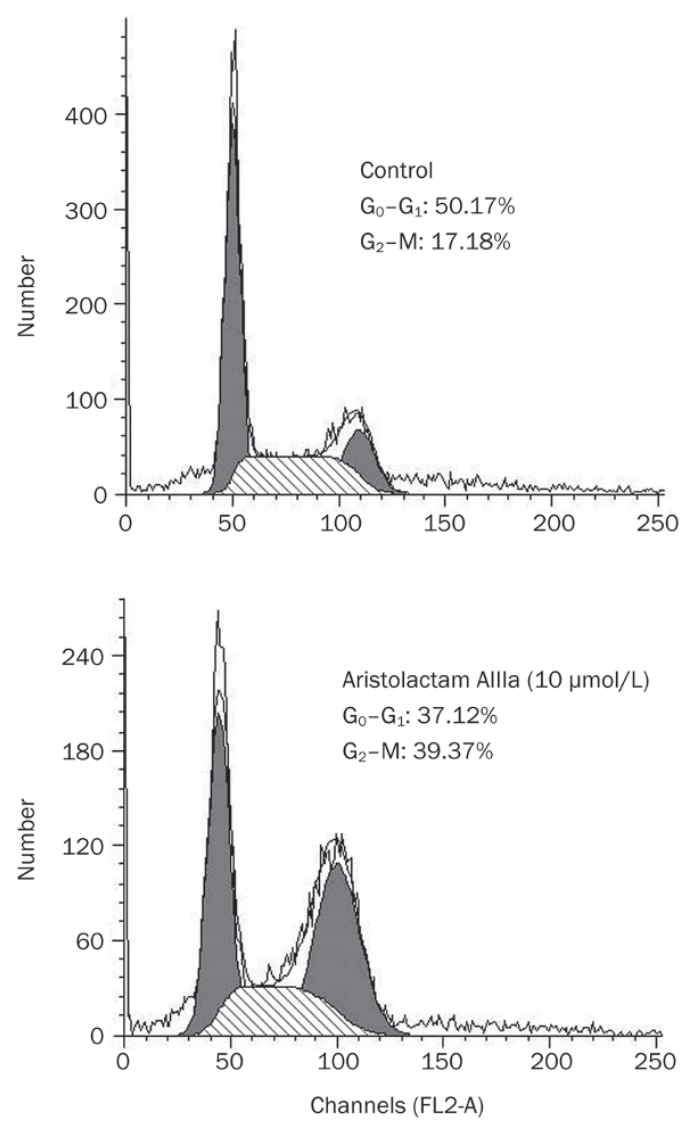

Figure S1. Aristolactam Allla could induce mitotic arrest of HeLa cells at $\mathrm{G}_{2} / \mathrm{M}$. Flow Cytometry result showed that the $\mathrm{G}_{2} / \mathrm{M}$ population of HeLa cells increased by $100 \%$ after $48 \mathrm{~h}$ incubation with the natural product Aristolactam Allla $(10 \mu \mathrm{mol} / \mathrm{L})$.

It has been known that Plk1 is involved in bipolar spindle formation which requires proper spindle assembly. Cells injected with anti-Plkl antibodies display striking defects in their ability to assemble bipolar spindles, as manifested by the lack of focused spindle poles and unstable attachment of the chromosomes to the spindles ${ }^{[8,29]}$. To test whether Aristolactam AIIIa could affect spindle assembly, we used confocal laser microscopy to image the spindle apparatus and chromosomes of Aristolactam AIIIa-treated cells. HeLa cells were incubated with either DMSO (as a control) or $10 \mu \mathrm{mol} /$ L of Aristolactam AIIIa for $12 \mathrm{~h}$, fixed with $4 \%$ paraformaldehyde, and then stained with FITC conjugated anti-a-tubulin antibody (to visualize tubulin spindles) and propidium iodide 
(to visualize chromosomal DNA). The images showed that the most DMSO-treated cells at mitosis phase exhibited no abnormality while $70 \%$ of the Aristolactam AIIIa-treated cells displayed multipolar spindles and misaligned chromosomes (Figure 2D and 2E). Such results were in agreement with the previous results for Plk1-depleted cells ${ }^{[29]}$, and suggested that Aristolactam AIIIa could induce aberrant spindle assembly in cells through its inhibition against Plk1.

\section{Aristolactam Allla induces apoptosis of cancer cells}

Considering that the activation of apoptotic pathways could be detected by examining PARP (Poly [ADP-ribose] polymerase-1) cleavage ${ }^{[30]}$, a marker for caspase activation, we thereby examined the potential effects of Aristolactam AIIIa on the apoptosis of HeLa cells by determining the induction of the cleaved PARP p85 fragment. Western blot analysis showed PARP cleavage in Aristolactam AIIIa-treated HeLa cells (Figure 3A), indicating the apoptosis induction in these cells. This result is consistent with the reported effects of Plk1 siRNA ${ }^{[31]}$ and other Plk1 inhibitors on cancer cells ${ }^{[20,32]}$.

To further confirm the above results, Aristolactam AIIIa (10 $\mu \mathrm{mol} / \mathrm{L})$ or DMSO-treated HeLa cells were labeled with
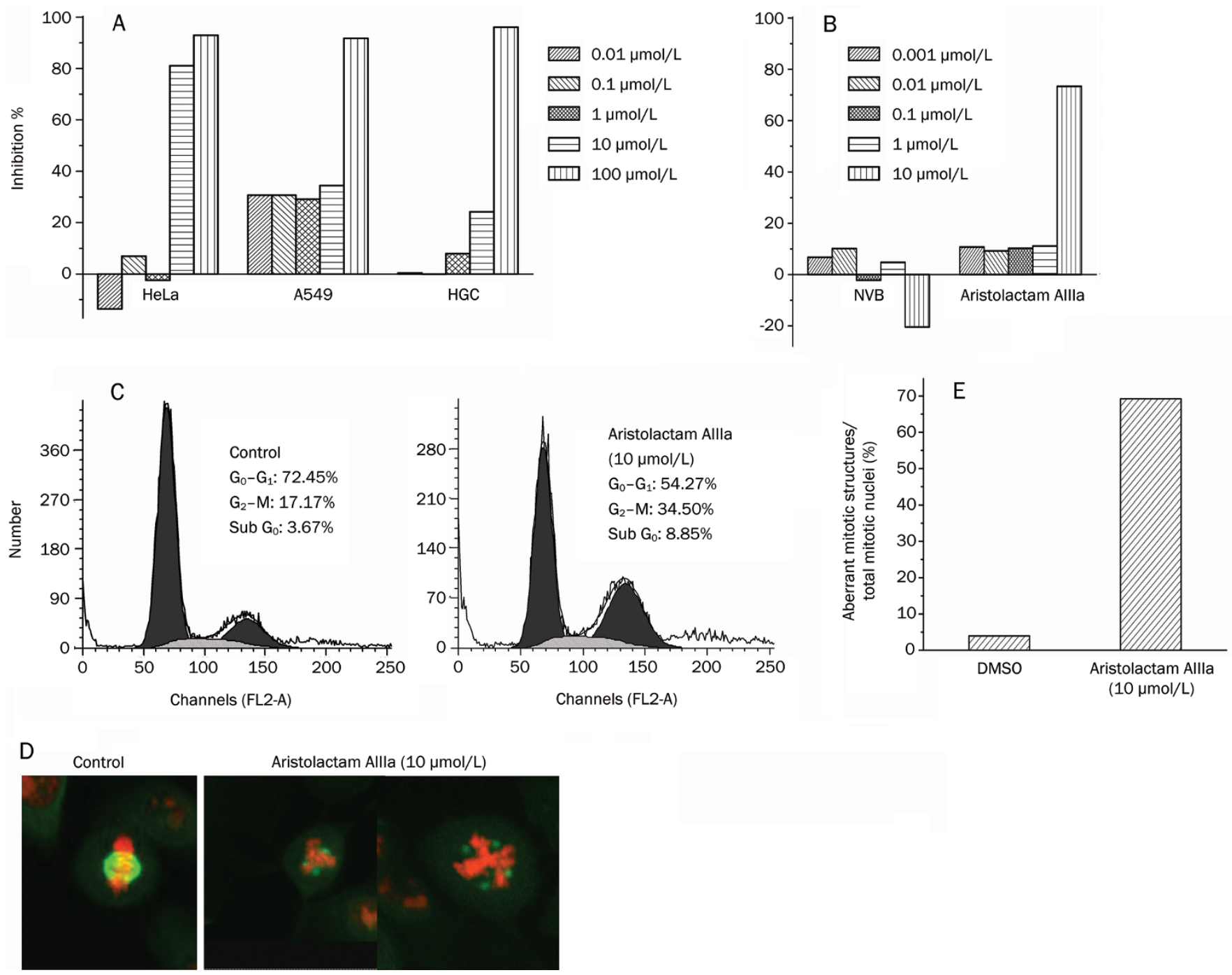

Figure 2. Aristolactam Allla could inhibit the proliferation of cancer cells and induce mitotic arrest at $G_{2} / M$ with spindle abnormalities. (A) Aristolactam Allla inhibited the proliferation of cancer cells in a dose-dependent manner. Hela, A549, and HGC cells were cultured in the presence of increasing concentrations of Aristolactam Allla. (B) Aristolactam Allla inhibited the proliferation of the clinical drug-resistant cell (HCT-8/V) in a dose-dependent manner. HCT-8/V cells were cultured in the presence of increasing concentrations of Aristolactam Allla or NVB. SRB assay was used to determine the cell viability. Each value was averaged from three independent experiments. Half-maximal inhibitory concentrations (IC $\mathrm{C}_{50}$ values) were obtained by sigmoidal fit of inhibitory curves using Origin 7.0. (C) Flow Cytometry result showed that the $G_{2} / M$ population of HeLa cells increased by $100 \%$ after being treated with the natural product Aristolactam Alla. (D) Aristolactam Allla induced spindle abnormalities in HeLa cells. HeLa cells were treated with either DMSO or $10 \mu \mathrm{mol} / \mathrm{L}$ of Aristolactam Alla for $12 \mathrm{~h}$, fixed with $4 \%$ paraformaldehyde, and stained with anti- $\alpha$-tubulin antibody (FITC conjugated) and propidium iodide. The cells were subsequently imaged by confocal laser microscopy. (E) The total percentage of mitotic nuclei with aberrant mitotic structures versus total mitotic nuclei in each treatment group was summarized after $12 \mathrm{~h}$ of Aristolactam Allla treatment to HeLa cells. 
A

Control Aristolactam Allla
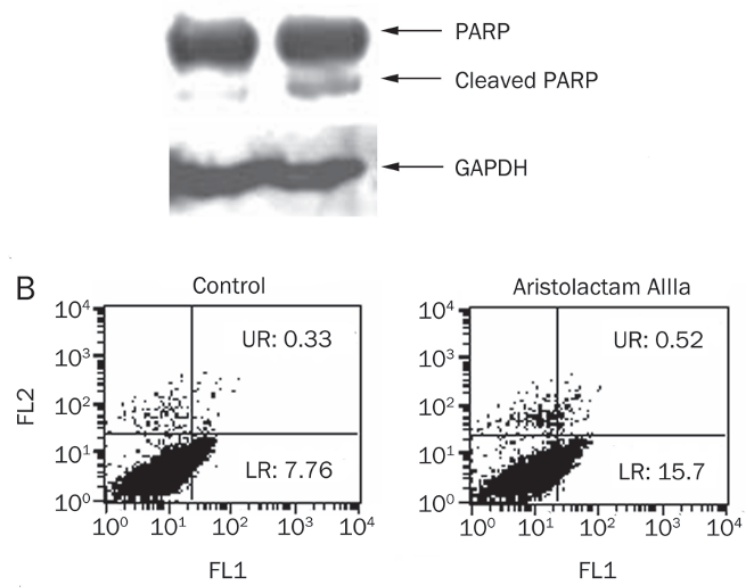

C

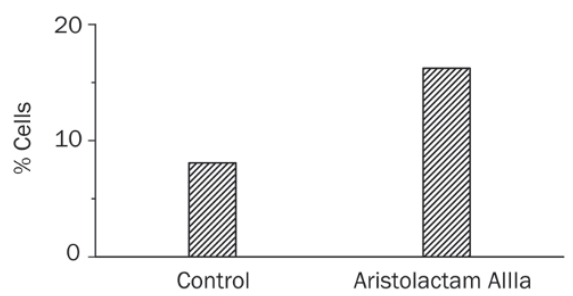

Figure 3. Aristolactam Allla induces apoptosis in cancer cells. (A) Western blot analysis of cell lysates treated with DMSO or Aristolactam Allla (10 $\mu \mathrm{mol} / \mathrm{L}$ ) using anti-PARP antibody to assess the cleavage of PARP. (B) HeLa cells treated with DMSO or Aristolactam Allla $(10 \mu \mathrm{mol} / \mathrm{L})$ for $24 \mathrm{~h}$ were stained using FITC-conjugated Annexin $\mathrm{V}$ and $\mathrm{PI}$ and subjected to flow cytometric analysis following the manufacturer's protocol. The lower right (LR) quadrant of the FACS histograms indicates the percentage of early apoptotic cells (Annexin V-positive) and the upper right (UR) quadrant indicates the percentage of late apoptotic cells (Annexin $\mathrm{V}$ - and PI-positive). (C) The total percentage of apoptotic cells in each treatment group was summarized after $24 \mathrm{~h}$ of Aristolactam Allla treatment to Hela cells.

Annexin V and PI to determine the extent of cellular apoptosis. As shown in Figure 3B and 3C, Aristolactam AIIIa induced an elevated percentage of apoptotic cells including early phase apoptosis (Annexin V-positive) and late phase apoptosis (Annexin V- and PI-positive) compared with DMSO-treated cells.

Moreover, this phenomenon was also confirmed by the analysis of the cell cycle distribution pattern of HeLa cells with $24 \mathrm{~h}$ incubation of Aristolactam AIIIa. As shown in Figure 2C, the population of sub- $G_{0} / G_{1}$ peaks were $3.67 \%$ (DMSO) and 8.85\% (Aristolactam AIIIa $10 \mu \mathrm{mol} / \mathrm{L}$ ), respectively, indicating Aristolactam AIIIa could induce apoptosis of cancer cells.

\section{Aristolactam Allla binds to the catalytic domain of Plk1 and} inhibits its activity

In order to further scrutinize the possible inhibition mechanism of Aristolactam AIIIa against Plk1, the binding and inhibition features of Aristolactam AIIIa against the Plk1 PBD and $\mathrm{CD}$ domains were characterized.
SPR technology-based Biacore 3000 instrument was used to carry out the kinetic analysis of Aristolactam AIIIa binding to the CD. In the assay, the 1:1 Langmuir binding fit model was used to determine the equilibrium dissociation constant $\left(K_{\mathrm{D}}\right)$, and the accuracy of the obtained results was evaluated by $x^{2}$. As indicated in Figure 4A and Table 3, Aristolactam AIIIa
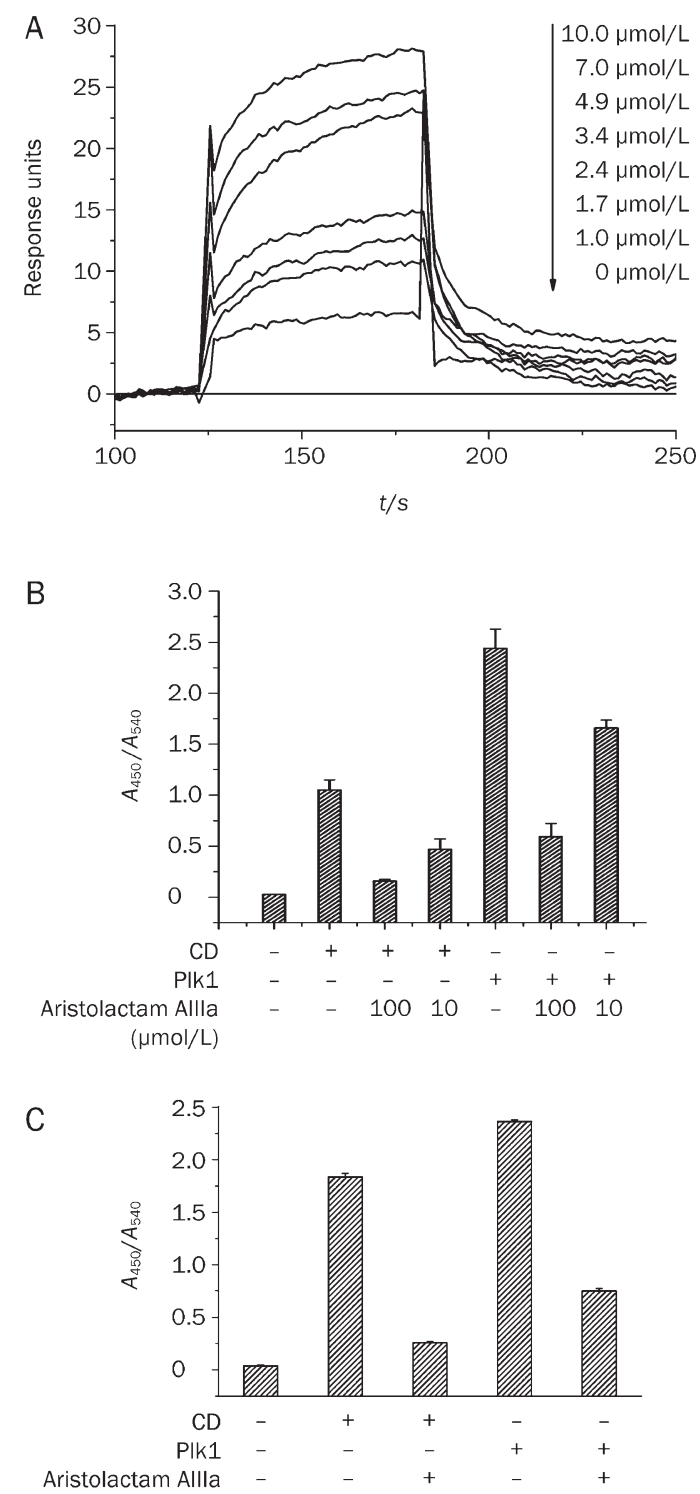

Figure 4. Aristolactam Allla binds to the catalytic domain (CD) of Plk1 and inhibits its activity. (A) SPR technology based kinetic analysis of $\mathrm{CD} /$ Aristolactam Allla interaction. Sensorgrams of Aristolactam Allla binding to CD measured by SPR technology based Biacore 3000 instrument. Representative sensorgrams were obtained from injecting Aristolactam Allla with concentrations of 0 , 1, 1.7, 2.4, 3.4, 4.9, 7.0, and $10.0 \mu \mathrm{mol} / \mathrm{L}$ over CD immobilized on the CM5 chip. (B) Inhibition of purified recombinant $\mathrm{CD}$ activity by Aristolactam Allla. $0.03 \mathrm{mg} / \mathrm{mL}$ of CD was mixed with DMSO (as a control) or Aristolactam Allla (100 $\mu \mathrm{mol} / \mathrm{L}$ and $10 \mu \mathrm{mol} / \mathrm{L}$ ) and the kinase activity was measured. (C) Inhibition of Aristolactam Allla against CD immunoprecipitated from transient transfected 293T cells. The kinase activity was measured by incubation with Aristolactam Allla (100 $\mu \mathrm{mol} / \mathrm{L})$ or DMSO (as a control). 
Table 3. SPR technology based kinetic analysis for PBD or CD/ Aristolactam Alla interaction.

\begin{tabular}{lcl}
\hline Target & $K_{\mathrm{D}}(\mu \mathrm{mol} / \mathrm{L}) *$ & $\chi^{2}$ \\
\hline CD & 1.44 & 0.353 \\
PBD & 2.99 & 3.28 \\
\hline
\end{tabular}

$\star K_{D}$, equilibrium dissociation constant; $x^{2}$, statistical value in BIAevaluation; $\mathrm{CD}$, catalytic kinase domain; PBD, polo box domain.

exhibits a high binding affinity against $\mathrm{CD}$ with a $K_{\mathrm{D}}$ of 1.44 $\mu \mathrm{mol} / \mathrm{L}$.

To test the enzymatic inhibition of Aristolactam AIIIa against the $\mathrm{CD}$, we conducted a similar kinase inhibition assay against the purified recombinant CD (residues 1-370 of Plk1). During the assay, after incubation of the CD with DMSO (as a control) or Aristolactam AIIIa $(100 \mu \mathrm{mol} / \mathrm{L}$ and $10 \mu \mathrm{mol} /$ L), the kinase activity was measured as described above. As indicated in Figure 4B, Aristolactam AIIIa exhibited a dosedependent inhibition against the $\mathrm{CD}$. To further confirm this inhibition, the kinase activity of the $\mathrm{CD}$ immunoprecipitated from the CD transient transfected 293T cells was also mea- sured as incubated with Aristolactam AIIIa $(100 \mu \mathrm{mol} / \mathrm{L})$ or DMSO (as a control). The results listed in Figure 4C have thereby validated the Aristolactam AIIIa inhibition against the CD.

Taken together, the above results have suggested that Aristolactam AIIla could directly bind the catalytic domain of Plk1 and inhibit its activity.

\section{Aristolactam Allla targets the PBD and increases the PBD/CD interaction}

The auto-inhibitory mechanism of Plk1 by its intrinsic Polo box domain (PBD) has made the PBD as another potential target besides the catalytic domain. To investigate whether Aristolactam AIIIa could interfere with PBD function through its binding to the PBD, the binding affinity of Aristolactam AIIIa against PBD was studied by using the SPR technology-based Biacore 3000 instrument. In the assay, immobilization of the $\mathrm{PBD}$ on the Biacore biosensor chip resulted in a resonance signal of 7540 resonance units (RUs). The results in Figure 5A indicated the dose-dependent biosensor RUs for Aristolactam AIIIa, suggesting that this natural product could bind to the PBD in vitro. The steady state affinity fit model was used to determine the equilibrium dissociation constant $K_{\mathrm{D}}$, and the
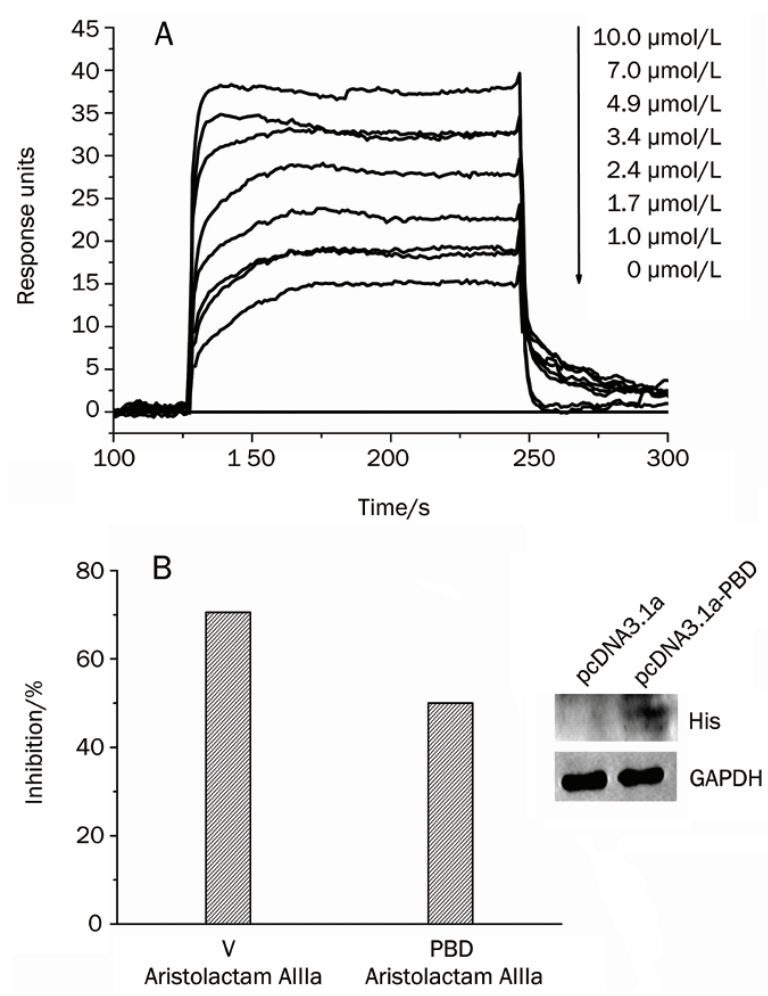

C

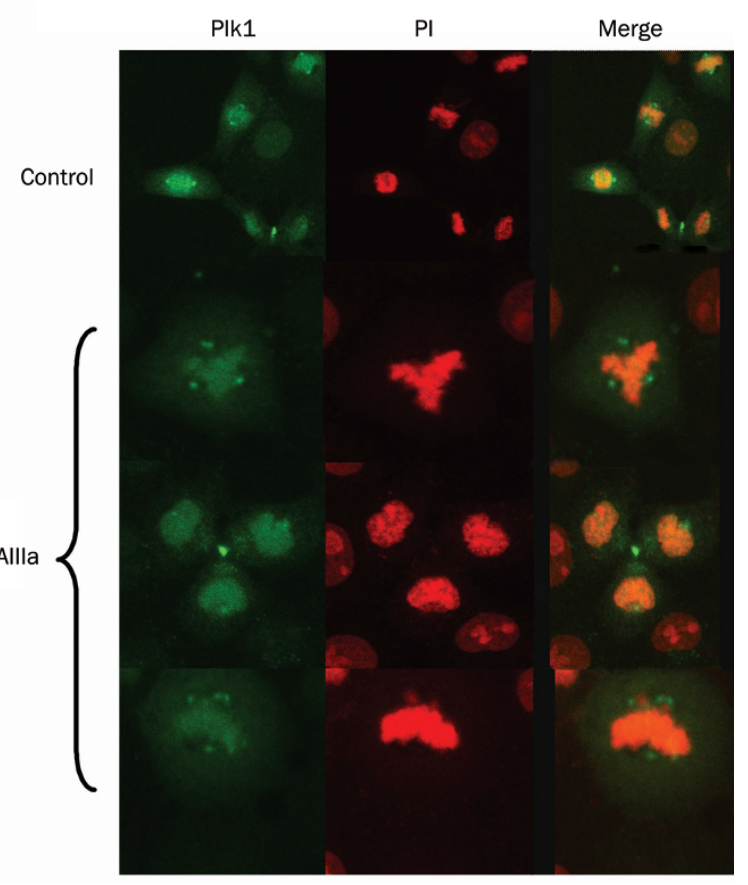

Figure 5. Aristolactam Allla targets polo box domain (PBD) and does not alters the localization of endogenous PIk1. (A) Sensorgrams of Aristolactam Allla binding to PBD measured by SPR technology based Biacore 3000 instrument. Representative sensorgrams were obtained from injecting Aristolactam Allla with concentrations of $0,1.2,1.7,2.4,3.4,4.9,7.0,9.0$, and $10.0 \mu \mathrm{mol} / \mathrm{L}$ over PBD immobilized on the CM5 chip. (B) Over expressing PBD could reduce the effect of Aristolactam Allla on Hela cells proliferation. HeLa cells transiently transfected with PBD-pcDNA3.1a or pcDNA3.1a were incubated Aristolactam Allla or DMSO respectively. SRB assay was used to determine the cell viability. Inset: the PBD protein level was increased by transfected pcDNA3.1a-PBD in HeLa cells. (C) Aristolactam Allla does not alter the localization of endogenous PIk1. Hela cells were treated with either DMSO or $10 \mu \mathrm{mol} / \mathrm{L}$ of Aristolactam Allla for $24 \mathrm{~h}$. Then the cells were analyzed by indirect immunofluorescence microscopy using an anti-PIk1 N-terminal antibody (green), PI (red). 
accuracy of the obtained results were evaluated by $x^{2}$. The fitted kinetic parameters listed in Table 3 thus demonstrated a strong binding affinity of Aristolactam AIIIa towards the PBD with a $K_{\mathrm{D}}$ value at $2.99 \mu \mathrm{mol} / \mathrm{L}$.

In addition, cell-based assay was also carried out to further examine the potential targeting of Aristolactam AIIIa against the PBD in the PBD over-expressing HeLa cells. After transient transfection with pCDNA3.1a-PBD, HeLa cells were incubated with Aristolactam AIIIa at $10 \mu \mathrm{mol} / \mathrm{L}$ for $48 \mathrm{~h}$. As shown in Figure 5B, Aristolactam AIIIa could exhibit inhibitory effects by $50 \%$ on the proliferation of the PBD overexpression in HeLa cells in the SRB assay. Compared with the $71 \%$ inhibition by Aristolactam AIIIa against the proliferation of the HeLa cells transfected with empty vector (Figure 5B), the result supports the finding that Aristolactam AIIIa targets the PBD.

Since the PBD plays a critical role in Plk subcellular localiza$\operatorname{tion}^{[33]}$ and Aristolactam AIIIa has been suggested to target the PBD as mentioned above, the localization of endogenous Plk1 in Aristolactam AIIIa or DMSO-treated HeLa cells was thereby examined by using an antibody directed against the $\mathrm{N}$ terminus of Plk1 (35-206 aa). As indicated in Figure 5C, in Aristolactam AIIIa-treated cells at mitosis phase, endogenous Plk1 was detected on spindle poles and concentrated close to the midbody in the postmitotic bridges connecting the dividing cells, which is consistent with the founded in DMSO-treated cells.

As has been reported, the PBD is believed to regulate Plk1 activity through its intramolecular interaction with the catalytic domain $(C D)^{[16,17]}$. Considering this fact, we have thus inspected the potential influence of Aristolactam AIIIa on the PBD/CD interaction by yeast two-hybrid system and SPR technology. In the yeast two-hybrid assay, the yeast cells transformed with both PBD and CD were incubated with either $100 \mu \mathrm{mol} / \mathrm{L}$ Aristolactam AIIIa or DMSO (as a control) for $48 \mathrm{~h}$. The result in Figure 6A implied that Aristolactam AIIIa increased the PBD binding to the catalytic domain of Plk1 by $\sim 43 \%$. Additionally, such Aristolactam AIIIa-stimulated $\mathrm{PBD} / \mathrm{CD}$ interaction was also confirmed in vitro by SPR technology-based assay (Figure 6B).

Summarily, all the above results indicated that Aristolactam AIIIa targets both the PBD and CD. It interferes with the PBD function through the inhibition of Plk kinase activity by increasing the PBD/CD interaction without affecting Plk1 localization to the proper subcellular substructure.

\section{Discussion}

Plk1 plays essential roles in numerous aspects of mitotic progression. A number of studies have demonstrated that Plk1 is over-expressed in a broad spectrum of human tumors ${ }^{[12]}$, and Plk1 has been determined as an attractive target for cancer therapy. To date, three kinds of small molecular inhibitors of Plk1 have been discovered: ATP competitive inhibitor, substrate competitive inhibitor and the PBD inhibitor.

In general, the ATP-binding domain is a regular target for protein kinase inhibitor discovery. However, specificity of
A
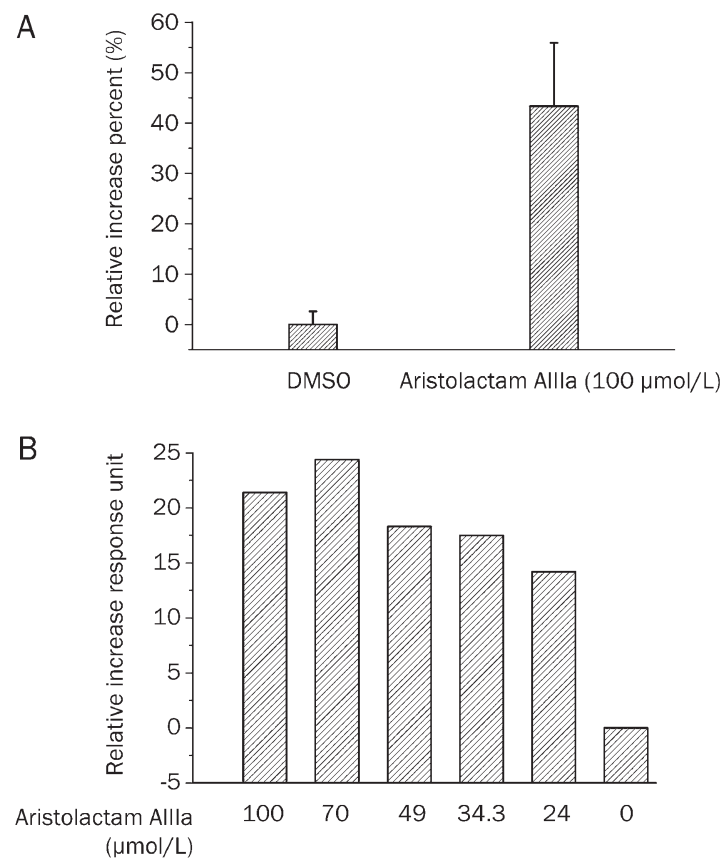

Figure 6. Aristolactam Allla could increase polo box domain (PBD) binding to the catalytic domain (CD) of PIk1. (A) Aristolactam Allla could increase PBD binding to $C D$ as indicated by the yeast two-hybrid technology based assay. The yeast strain AH109 transformed with both PBD and CD was incubated with either $100 \mu \mathrm{mol} / \mathrm{L}$ of Aristolactam Allla or DMSO (as a control) for $48 \mathrm{~h}$. The growth curve was tested by measure the absorbance at $600 \mathrm{~nm}$ of the culture. (B) Aristolactam Allla could increase PBD binding to CD by SPR experiment. The RU values were obtained by injection of PBD $(14 \mu \mathrm{mol} / \mathrm{L})$ incubated with series of concentrations of Aristolactam Allla over the immobilized CD surface.

such target-based inhibitor is difficult to obtain due to the high degree of structural conservation among ATP-binding pockets, and only a few ATP-like inhibitors of Plk1 have so far been published. The first small molecule Plk1 inhibitor was scytonemin, a non-specific ATP competitor, which exhibited comparable potencies against other Ser/Thr and Thr/Tyr kinases including MYT1, CHK1, CDK1, and PKC ${ }^{[18,19]}$.

Exploration of Plk1 non-ATP competitor is another choice for a Plk1 specific inhibitor in anti-tumor drug discovery. For example, the pharmacophore ON01910 was reported to be a substrate-competitive inhibitor of recombinant casein and CDC25C ${ }^{[20]}$. Another strategy in the development of Plk1 specific inhibitor is to target the PBD, which has a critical role in the regulation of the kinase activity and the subcellular localization of Plk ${ }^{[16]}$. Recently, the first small molecule targeting the PBD was reported, which could interfere with Plk1 intracellular localization by inhibiting the function of the $\mathrm{PBD}^{[21]}$.

Aristolactams are phenanthrene lactam alkaloids that are structurally and biogenetically related to aporphines, which have been reported to show inhibitory activity against cancer cell proliferation; however, the relevant detailed data still remain unclear ${ }^{[23,24]}$. As a member of Aristolactams, Aristolactam AIIIa demonstrated significant inhibition of platelet 
aggregation induced by collagen and $\mathrm{AA}^{[27]}$, while its antitumor activity has not yet been elucidated. By random screening against the in-house natural product library, we discovered that Aristolactam AIIIa functions as a new type of ligand targeting the PBD, as investigated by the SPR and enzymatic inhibition assays. It could inhibit the proliferation of HeLa, A549, HGC, and HCT-8/V cells, influence cell cycle progression and spindle assembly in HeLa cells and induce the apoptosis in HeLa cells.

Enzymatic characterization indicated that Aristolactam AIIIa could exhibit inhibition activity against the $C D$, which might contribute to its inhibition against the full length Plk1 in vitro, similar to previously published inhibitors ${ }^{[20,32]}$.

To further investigate the potential inhibition mechanism of Aristolactam AIIIa against Plk1, the kinetic feature of Aristolactam AIIIa binding to the PBD was assayed. SPR results demonstrated a strong binding affinity of Aristolactam AIIIa to the PBD $\left(K_{\mathrm{D}}=2.99 \mu \mathrm{mol} / \mathrm{L}\right)$. Since the PBD has a critical role in the regulation Plk's kinase activity by interacting with the catalytic domain of Plk1 $1^{[16,17]}$, the result that Aristolactam AIIIa could enhance the PBD interaction with the $\mathrm{CD}$ as indicated by SPR and yeast two-hybrid-based assays has shown that this natural product further strengthened the self-regulatory effect of the PBD on Plk1.

It is noticed that the small molecule inhibitors reported by Reindl et al ${ }^{[21]}$ inhibited the function of the Plk1 PBD and interfered with the intracellular localization of Plk1, while Aristolactam AIIIa did not affect the localization of Plk1. Such discrepancy might possibly come from the different PBD binding sites for the compounds. The reported inhibitors ${ }^{[21]}$ interfered with the interaction between PBD and its intracellular anchoring sites of the substrates, resulting in mis-localization of Plk1. However, Aristolactam AIIIa enhanced the CD/PBD interaction, thereby inhibiting Plk1 activity without affecting Plk1 localization. All these findings thus revealed that the regulation of PBD in Plk1's kinase activity and the subcellular localization of Plk1 are closely related to the PBD binding sites.

In summary, we have identified the Aristolactam derivative, Aristolactam AIIIa as a new type of ligand targeting the PBD by random screening our in-house natural product library. Cell-based assays indicated that this natural product could inhibit the proliferation of HeLa, A549, HGC, and HCT- $8 / V$ cells, induce mitotic arrest at the $G_{2} / M$ phase with spindle abnormalities and promote apoptosis. Different from the published Plk1 inhibitors, Aristolactam AIIIa could bind to the interaction interface of $\mathrm{CD} / \mathrm{PBD}$ due to targets both the catalytic domain and the polo-box domain of Plk1 kinase, and enhances the CD/PBD interaction. Our current work is expected to shed light on the potential antitumor mechanism of Aristolactam AIIIa, and this determined Plk1 inhibitor may also be used as a lead compound for further research.

\section{Abbreviations}

Plk1: Polo-like kinase 1; CD: catalytic domain of Plk1; PBD: Polo box domain; HeLa: cell line taken from Henrietta Lacks alias Helen Lane; A549: human lung cancer A549 cell line; HGC: human gastric cancer cell line; HCT-8/V: human colon adenocarcinoma cell line resistant to vincristine; SPR: Surface Plasmon Resonance; Plks: Polo-like kinases; Plk2: Polo-like kinase 2; SNK: serum inducible kinase; Plk3: Polo-like kinase 3; PRK: proliferation-related kinase; FNK: fibroblast growth factor-inducible kinase; Plk4: Polo-like kinase 4; SAK: Snk/Plk- $\alpha$ kin kinase; cdc2: cell division cycle 2 (cell cycle-dependent protein kinase); NudC: nuclear distribution gene C; NIH 3T3: mouse embryonic fibroblast cell line; ASONs: phosphorothioate antisense oligonucleotides; CDC25C: cell division cycle 25 homolog C; DMSO: dimethyl sulfoxide; HRP: horseradish peroxidase; $293 \mathrm{~T}$ cell line: a derivative of human embryonic kidney cells line that stably express the large T-antigen of SV40; SRB: sulphorhodamine B; NVB: navelbine; PBS: phosphate-buffered saline; FITC: fluorescein isothiocyanate; PI: propidium iodide; PARP: poly [ADP-ribose] polymerase-1; sscarrier DNA: salmon sperm-carrier DNA; SD medium: synthetic defined medium; 3-AT: 3-amino-10, 20, 40-triazole; $\mathrm{IC}_{50}$ : concentration giving $50 \%$ of maximal inhibition; KB: human carcinoma cell (strain KB); P388: murine lymphoma cell (strain P388); HT29: a colon adenocarcinoma cell line ( HT-29); HL60: human promyelocytic leukemia 60 cell line; L1210 cells: L1210 mouse leukemia cells; AA: arachidonic acid; $K_{\mathrm{D}}$ : dissociation constant; RUs: resonance units; MYT1: membrane-associated tyrosine- and threoninespecific cdc2-inhibitory kinase; CHK1: checkpoint kinase 1; CDK1: cyclin dependent kinase 1; PKC: protein kinase C.

\section{Acknowledgements}

This work was supported by the State Key Program of Basic Research of China (grants 2010CB912501, 2009CB918502), the National Natural Science Foundation of China (grant 30890044), Shanghai Basic Research Project from the Shanghai Science and Technology Commission (grant 0811141013) and the Knowledge Innovation Program of the Chinese Academy of Sciences (grant SIMM0709QN-19).

\section{Author contribution}

This study was designed by $\mathrm{Xu}$ WANG, Li LI, Jing CHEN, and Li-hong HU. The surface plasmon resonance (SPR) technology-based assay, enzymatic inhibition assay and cell-based assays which were used to screen and further identify Plk1 inhibitor were performed by Xu WANG, Li LI, Hong DING, and Jing CHEN. The experiments about investigating the potential inhibition mechanism of active compound against Plk1 were performed by Hong DING, Yu ZHANG, and Jing CHEN. Xu SHEN, Hua-liang JIANG, and Li-hong HU supervised the project. Li LI, Jing CHEN, Tian-cen HU, and Xu SHEN contributed to the manuscript writing. All authors read and approved the final manuscript.

\section{References}

1 Glover DM, Hagan IM, Tavares AA. Polo-like kinases: a team that plays throughout mitosis. Genes Dev 1998; 12: 3777-87.

2 Hamanaka R, Maloid S, Smith MR, O'Connell CD, Longo DL, Ferris DK. Cloning and characterization of human and murine homologues of the Drosophila polo serine-threonine kinase. Cell Growth Differ 1994; 5: 249-57.

3 Simmons DL, Neel BG, Stevens R, Evett G, Erikson RL. Identification of an early-growth-response gene encoding a novel putative protein kinase. Mol Cell Biol 1992; 12: 4164-9. 
4 Donohue PJ, Alberts GF, Guo Y, Winkles JA. Identification by targeted differential display of an immediate early gene encoding a putative serine/threonine kinase. J Biol Chem 1995; 270: 10351-7.

5 Ouyang B, Pan H, Lu L, Li J, Stambrook P, Li B, et al. Human Prk is a conserved protein serine/threonine kinase involved in regulating $M$ phase functions. J Biol Chem 1997; 272: 28646-51.

6 Fode C, Motro B, Yousefi S, Heffernan M, Dennis JW. Sak, a murine protein-serine/threonine kinase that is related to the Drosophila polo kinase and involved in cell proliferation. Proc Natl Acad Sci USA 1994; 91: 6388-92.

7 Roshak AK, Capper EA, Imburgia C, Fornwald J, Scott G, Marshall LA. The human polo-like kinase, PLK, regulates cdc2/cyclin B through phosphorylation and activation of the cdc25C phosphatase. Cell Signal 2000; 12: 405-11.

8 Lane HA, Nigg EA. Antibody microinjection reveals an essential role for human polo-like kinase 1 (Plk1) in the functional maturation of mitotic centrosomes. J Cell Biol 1996; 135: 1701-13.

9 Sumara I, Vorlaufer E, Stukenberg PT, Kelm O, Redemann N, Nigg EA, et al. The dissociation of cohesin from chromosomes in prophase is regulated by Polo-like kinase. Mol Cell 2002; 9: 515-25.

10 Kotani S, Tugendreich S, Fujii M, Jorgensen PM, Watanabe N, Hoog $\mathrm{C}$, et al. PKA and MPF-activated polo-like kinase regulate anaphasepromoting complex activity and mitosis progression. Mol Cell 1998; 1 : 371-80.

11 Zhou T, Aumais JP, Liu X, Yu-Lee LY, Erikson RL. A role for Plk1 phosphorylation of NudC in cytokinesis. Dev Cell 2003; 5: 127-38.

12 Strebhardt K, Ullrich A. Targeting polo-like kinase 1 for cancer therapy. Nat Rev Cancer 2006; 6: 321-30.

13 Smith MR, Wilson ML, Hamanaka R, Chase D, Kung H, Longo DL, et al. Malignant transformation of mammalian cells initiated by constitutive expression of the polo-like kinase. Biochem Biophys Res Commun 1997; 234: 397-405.

14 Spänkuch-Schmitt B, Wolf G, Solbach C, Loibl S, Knecht R, Stegmüller $\mathrm{M}$, et al. Downregulation of human polo-like kinase activity by antisense oligonucleotides induces growth inhibition in cancer cells. Oncogene 2002; 21: 3162-71.

15 Elez R, Piiper A, Kronenberger B, Kock M, Brendel M, Hermann E, et al. Tumor regression by combination antisense therapy against Plk1 and Bcl-2. Oncogene 2003; 22: 69-80.

16 Jang YJ, Lin CY, Ma S, Erikson RL. Functional studies on the role of the C-terminal domain of mammalian polo-like kinase. Proc Natl Acad Sci USA 2002; 99: 1984-9.

17 Elia AE, Rellos P, Haire LF, Chao JW, Ivins FJ, Hoepker K, et al. The molecular basis for phosphodependent substrate targeting and regulation of Plks by the Polo-box domain. Cell 2003; 115: 83-95.

18 Stevenson CS, Capper EA, Roshak AK, Marquez B, Eichman C, Jackson $\mathrm{JR}$, et al. The identification and characterization of the marine natural product scytonemin as a novel antiproliferative pharmacophore. J Pharmacol Exp Ther 2002; 303: 858-66.

19 Stevenson CS, Capper EA, Roshak AK, Marquez B, Grace K, Gerwick $\mathrm{WH}$, et al. Scytonemin - a marine natural product inhibitor of kinases key in hyperproliferative inflammatory diseases. Inflamm Res 2002; 51: 112-4.

20 Gumireddy K, Reddy MV, Cosenza SC, Boominathan R, Baker SJ, Papathi N, et al. ON01910, a non-ATP-competitive small molecule inhibitor of Plk1, is a potent anticancer agent. Cancer Cell 2005; 7: 275-86.

21 Reindl W, Yuan J, Krämer A, Strebhardt K, Berg T. Inhibition of pololike kinase 1 by blocking polo-box domain-dependent protein-protein interactions. Chem Biol 2008; 15: 459-66.

22 Priestap HA. Seven aristololactams from Aristolochia Argentina. Phytochemistry 1985; 24: 849-52.

23 Couture A, Deniau E, Grandclaudon P, Rybalko-Rosen H, Léonce S, Pfeiffer B, et al. Synthesis and biological evaluation of Aristolactams. Bioorg Med Chem Lett 2002; 12: 3557-9.

24 Kumar V, Poonam, Prasad AK, Parmar VS. Naturally occurring Aristolactams, aristolochic acids and dioxoaporphines and their biological activities. Nat Prod Rep 2003; 20: 565-83.

25 Skehan P, Storeng R, Scudiero D, Monks A, McMahon J, Vistica D, et al. New colorimetric cytotoxicity assay for anticancer-drug screening. J Natl Cancer Inst 1990; 82: 1107-12.

26 Diaz-Camino C, Risseeuw EP, Liu E, Crosby WL. A high-throughput system for two-hybrid screening based on growth curve analysis in microtiter plates. Anal Biochem 2003; 316; 171-4.

27 Chia YC, Chang FR, Teng CM, Wu YC. Aristolactams and dioxoaporphines from Fissistigma balansae and Fissistigma oldhamii. J Nat Prod 2000; 63: 1160-3.

28 Cogswell JP, Brown CE, Bisi JE, Neill SD. Dominant-negative pololike kinase 1 induces mitotic catastrophe independent of cdc $25 \mathrm{C}$ function. Cell Growth Differ 2000; 11: 615-23.

29 Sumara I, Giménez-Abián JF, Gerlich D, Hirota T, Kraft C, de la Torre C, et al. Roles of polo-like kinase 1 in the assembly of functional mitotic spindles. Curr Biol 2004; 14: 1712-22.

30 Soldani C, Scovassi Al. Poly (ADP-ribose) polymerase-1 cleavage during apoptosis: an update. Apoptosis 2002; 7: 321-8.

31 Liu X, Erikson RL. Polo-like kinase (PIk) 1 depletion induces apoptosis in cancer cells. Proc Natl Acad Sci USA 2003; 100: 5789-94.

32 Steegmaier M, Hoffmann M, Baum A, Lénárt P, Petronczki M, Krssák $\mathrm{M}$, et al. BI 2536, a potent and selective inhibitor of polo-like kinase 1, inhibits tumor growth in vivo. Curr Biol 2007; 17: 316-22.

33 Lee KS, Grenfell TZ, Yarm FR, Erikson RL. Mutation of the polo-box disrupts localization and mitotic functions of the mammalian polo kinase PIk. Proc Natl Acad Sci USA 1998; 95: 9301-6. 